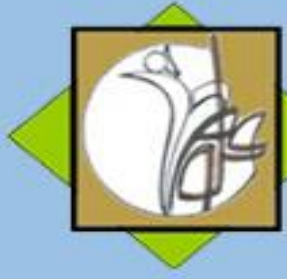

\author{
Research Article
}

\title{
Focus of Attention: a Challenge on Predicting Constrained Action Hypothesis
}

\author{
Rasoul Yaali ${ }^{1}$, Sara Oftadeh ${ }^{2}$, Asma Mahmoodi ${ }^{3}$ \\ 1. Rasoul Yaali, (Ph.D) Kharazmi University of Tehran, Tehran, Iran \\ 2. Sara Oftadeh, (Ph. D Student) Kharazmi University of Tehran, Tehran, Iran \\ 3. Asma Mahmoodi, (Ms.c) Kharazmi University of Tehran, Tehran, Iran
}

\section{ARTICLE INFO}

Received May 2017

Accepted October 2017

\section{KEYWORDS:}

Constrained Action Hypothesis,

Focus of Attention,

Badminton Backhand Serve,

Probe Task.

\section{CITE:}

Yaali, Oftadeh, Mahmoodi, Focus of Attention: a Challenge on Predicting Constrained Action Hypothesis, Research in Sport Management \& Motor Behavior, 2020: $10(20): 124-137$

\section{ABSTRACT}

Focus of attention instruction has a great influence on performance and learning. The purpose of this study was to examine the predicted constrained action hypothesis in badminton backhand serv. 30 women student participants from physical education classes of University of Kharazmi are selected as sample. Participants are tested in probe task at different stage of serve after identifying base of reaction time, and level of attention demanding of different parts was measured. Then participants divided into two groups (internal and external focus of attention) and they are tested with their specific instruction again. The results revealed that first stage of serve has the most attention need $(p<0 / 001)$, but there is not any difference between two groups and different serve stage in the effect of focus of attention type. Accordance with these results the constrained action hypothesis at discrete skills is not confirmed. 


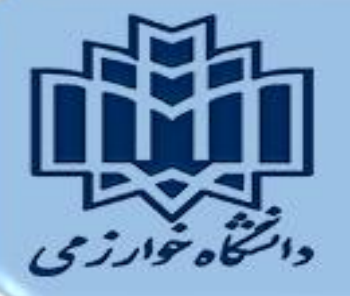

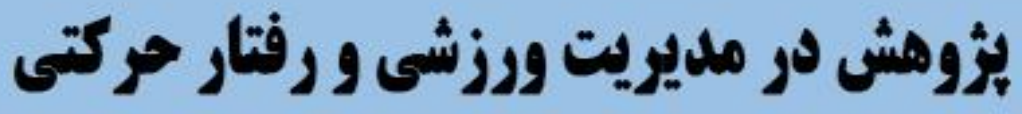

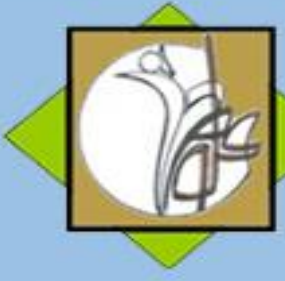

مقاله بُؤوهشى

تمر كز توجه: جالشى بر ييش بينى هاى نظريه عمل محددود شده

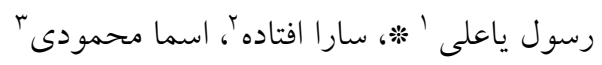

1. استاديار كروه رفتار حركتى، دانشكده تربيت بدنى و علوم ورزشى دانشكاه خوارزمى تهران، تهران، ايران

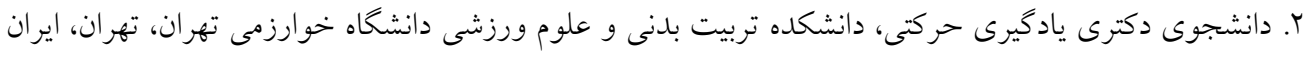

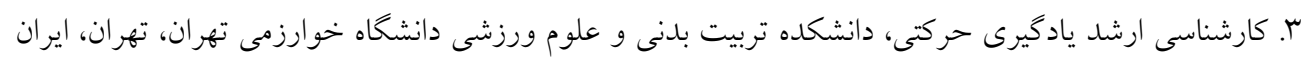

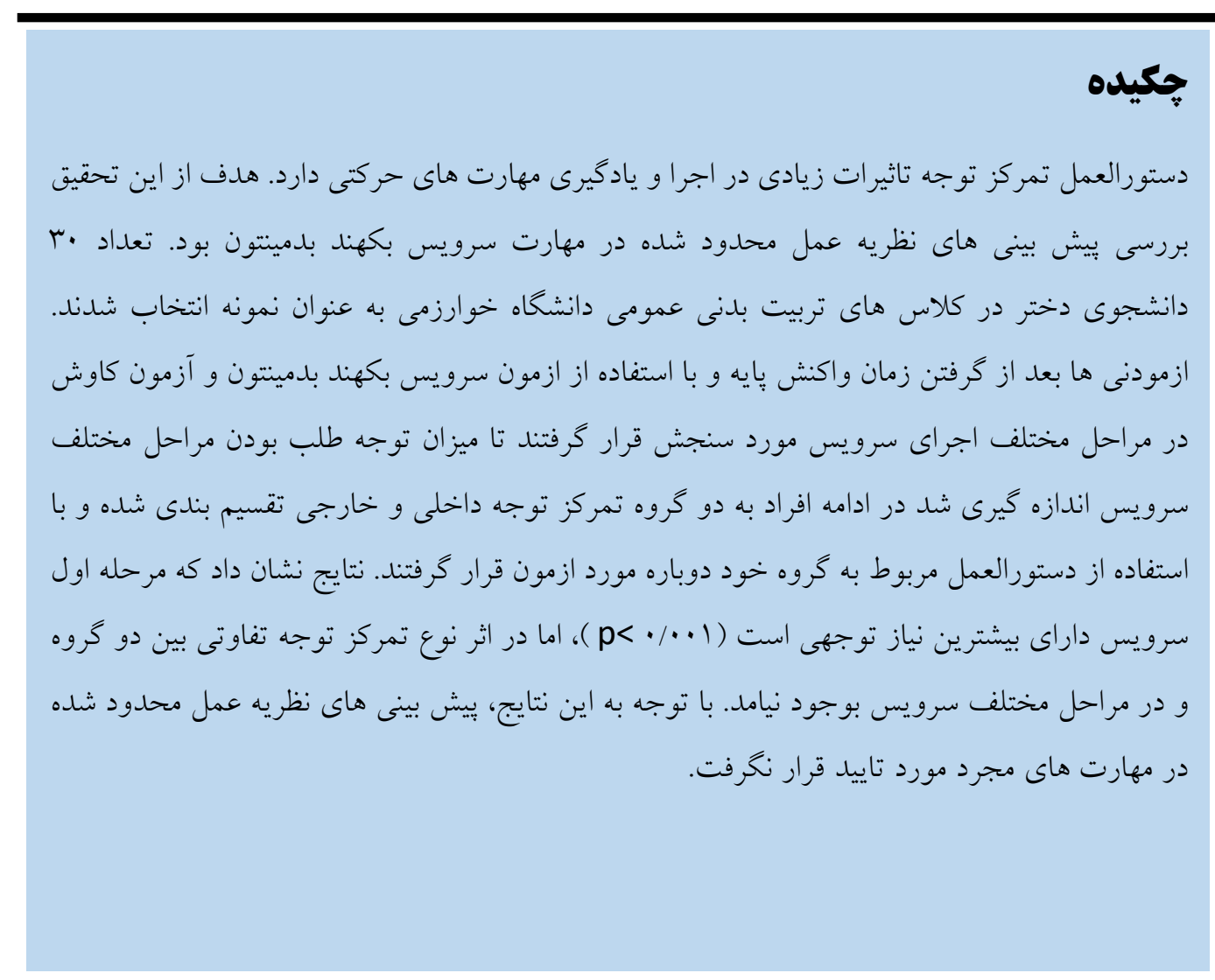

اطلاعات مقاله:

دريافت مقاله ارديبهشت

بذيرش مقاله مهر 97"

:نويسنده مسنول:

r.yaali@gmail.com

وازه هاى كليلىى:

نظريه عمل محدود شده،

تمركز توجه، سرويس بكهند

بلدميتتون، تكليف كاوش

ارجاع:

ياعلى، افتاده، محمودى، تمركز توجه: جالشى بر بِيش بينى هاى نظريه عمل محدود شده. يزوهش در مديريت

ورزشى و رفتار حركتى، 99 19

$|r \varepsilon-| r V:\left(r_{\cdot}\right) \mid$. 


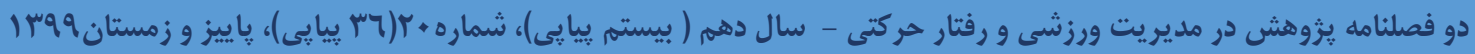

مقـلدمه

اجراى موفق مهارتهاى ورزشى در شرايط مسابقه يكى از جالشهاى مربيان و بازيكنان در همه سطوح مىباشد. براى انجام يك حركت موفق نياز به فعال سازى عضلات به ترتيب خاص و تبع آن اجراى قطعات مختلف يك مهارت به صورت متوالى مى باشد. ورزشكاران ماهر اغلب از اين توالى به صورت هوشيار آكاه نيستند و نحوه كنترل عضلات مورد نياز هر بخش را نيز نمىدانند اما در حين آموزش مهارتهاى حركتى جديد توجه به اين موضوع بيشتر آشكار مى گردد. در حين يادكيرى يك مهارت جديد نياز است به بخش هايى از بدن يا مهارت توجه شود كه بر اجراى تكليف اثر كذار بوده و بهترين نتيجه را ايجاد كند. تحقيقات كذشته مشخص كرده است در بيشتر مهارت ها توجه به اثر مهارت (نسبت به تمركز بر خود مهارت در محيط) نتايج بهترى بوجود مى آورد مثلا دوجرمه و همكاران (17)(1) (1) در تحقيقى نشان دادند علاوه بر طول يرش، زاويه يرش و اوج نيروى گروه با تمركز توجه خارجى در تكليف يرش طول به طور معنى دارى بهتر از كروه ديخر بود. اين كونه تحقيقات در مورد دقت زدن به هدف (Y)، توليد نيروى معين (ז)، سرعت حركت

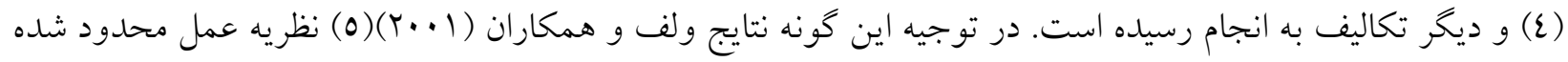
را ارائه كردند كه بر اساس آن تمركز توجه خارجى باعث مى شود نوعى كتترل خودكار در اجراى مهارت بوجود آيد كه شرايط اكتساب و اجراى مهارت را تسهيل خواهد كرد.

در جهت اثبات بيش بينى هاى اين نظريه تحقيقات متعددى انجام شده است و در مهارت هاى مختلف متغير هاى متفاوتى از اجراى افراد را در همه سطوح مورد بررسى قرار داده اند. اغلب آنها به اين نتيجه رسيده اند كه جلب توجه اجرا كننده به اثر مهارت در محيط (تمركز توجه خارجى) به اين دليل باعث اجراى بهتر خواهد شد كه فرايندهاى اجراى مهارت بهبود يافته و به نوعى به حالت خودكارى خواهد رسيد و حتى ميزان فعالسازى عضلات، بيشينه اكسيزن مصرفى و ... نيز

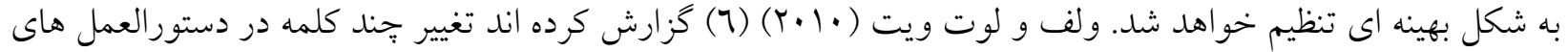
آموزشى باعث ايجاد زنجيره ای از وقايع مى كردد كه نوع كنترل و يادكيرى حركت را تغيير خواهد داد. در واقع تمركز توجه خارجى باعث كنترل خودكار حركت شده و كنترلى ناهوشيار، سريع و بازتابى را بوجود خواهد آورد كه در اثر آن

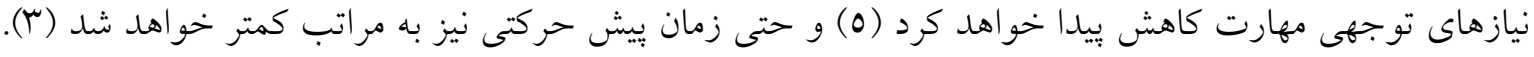

از طرف ديكر يكى از دلايل افت عملكرد در حين اجراى مهارت هاى ورزشى به ويزه در محيط هاى رقابتى و در مقابل تماشاجيان، محدوديت هاى ظرفيت توجه در انسان است. تحقيقات نشان داده اند يا در سيستم پردازشى انسان تنخراهى در زمينه توجه وجود دارد كه در يك لحظه نمى تواند بيش از يك تكليف را از خود عبور دهد (نظريه گردن بطرى) و يا 


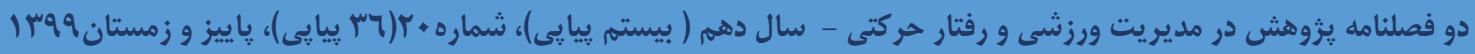

ظرفيت محدود منبع توجهى موجود در سيستم يردازشى با ورود يك محرى توجه طلب ديخر قادر به يردازش محرى دوم نخو اهد بود (نظريه ظرفيتى). تحقيقات در اين مورد پا را فراتر از اين كذاشته و نشان داده اند حتى هر بخش از يك مهارت نيز ميزان توجه طلبى متفاوتى از بخش هاى ديخر دارد به طورى كه در حين اجراى يك مهارت ممكن است تنها مثلا بخش ميانى يك مهارت مشكل بزرگ اجراى ان مهارت بوده و ديخر بخشها به راحتى قابل اجرا باشند. شناسايى اين بخش هاى داراى بيشترين نياز توجهى، از اين جهت قابل تامل است كه مربيان با استفاده از راهكارهاى آموزشى محرى هاى مخرب را حداقل در ان بخش مهارت به حداقل برسانند. يك مهارت ورزشى از جندين بخش تشكيل شده است كه

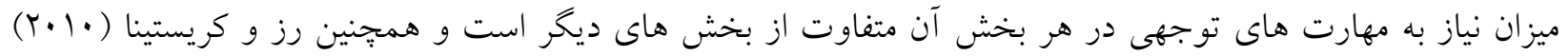
ييش بينى كرده اند نيازهاى توجهى در هر مهارت نيز ويزه همان مهارت است. تحقيقات متعددى در مورد تعيين نيازهاى تو جهى مهارت هاى گوناگون توسط محققين مختلف انجام شده است. براى بررسى اين موضوع در ادبيات رفتار حركتى از تكليف كاوش استفاده مى كردد. مثلا ياعلى و همكاران (IT (IT) نشان دادند در مهارت اسمش بدمينتون، بخش دوم مهارت داراى بيشترين نياز توجهى است. كاستيلو و اميلتا (1911) (9) از اين روش براى شناسايى زمان اوج توجه در جندين تكليف ورزشى همانند دريافت سرويس واليبال، دوى · · متر، دوى • ل1 متر با مانع و دريافت سرويس

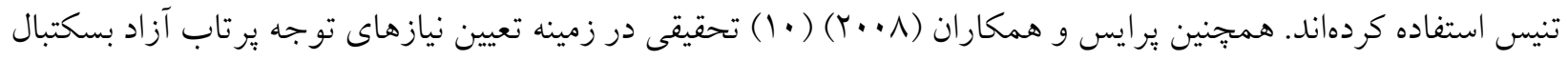
انجام دادند. به اين منظور آنها يرتاب آزاد را به جهار بخش تقسيم كردند. نتايج اين تحقق نشان داد كه بخش اول مهارت بيشترين نياز توجه را به خود اختصاص مى دهد و ديخر بخشها به صورت خودكار و با كمترين نياز توجه اجرا مىشود. با توجه به نظريه عمل محدود شده و بيش بينى اين نظريه مبنى بر كاهش نيازهاى توجهى مورد نياز يك مهارت در صورت استفاده از تمركز توجه خارجى، اين كونه برداشت مى شود كه در صورت تغيير در نوع تمركز توجه، ممكن است به همين دليل، نيازهاى توجهى هر بخش از مهارت نيز كاهش يابد. در اين زمينه ولف و همكاران (11 (T) (7) تحقيقى انجام دادند انها در يك تكليف تعادل يويا از دو كروه با تمركز توجه داخلى و تمركز توجه خارجى استفاده كردند. در حين اجرا، محققان يك تكليف كاوش صوتى را در زمانهاى مختلف اجراى مهارت، به افراد ارائه دادند. نتايج نشان داد كروه تمركز توجه خارجى نيازهاى توجهى كمترى نسبت به كروه تمركز توجه داخلى داشت كه محققان اين نتيجه را به كنترل خودكار مهارت در اثر تمركز توجه خارجى نسبت دادند. اما نكته قابل توجه در اين تحقيق اين است كه محققان با اين توجيه كه مهارت استفاده شده در اين آزمايش يك مهارت مداوم بوده، اين مهارت را بخش هاى جداكانه تقسيم نكرده و نيازهاى توجهى هر بخش را محاسبه نكرده اند. از طرف ديخر ممكن است ميزان كاهش در نيازهاى توجهى بخش هاى مختلف مهارت با نسبت يكسانى انجام نكيرد همجنين شايد بخش داراى بيشترين نياز توجهى، دجار بيشترين كاهش در 


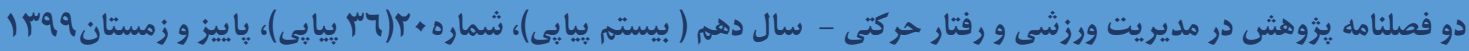

تقاضاى توجهى گردد تا برابر نظر ولف و همكاران (1. (Y) (0) تمامى بخش ها داراى نياز توجهى كم و يكسانى كردند و كتترل خود كار و بازتابى حاصل گردد. و يا حتى جابجايى مشهودى در بخش توجه طلب مهارت ايجاد شود. به همين دليل در اين يزوهش با استفاده از يك مهارت مجرد، موارد اخير را مورد بررسى قرار مى گيرد تا ضمن بررسى نياز هاى توجهى سرويس بكهند بدمينتون در هنخام توجه داخلى و خارجى، بيش بينى هاى فرضيه عمل محدود بار ديخر مورد آزمون قرار كيرد.

\section{روش شناسى:}

\section{شركت كنندكان}

طرح تحقيق حاضر از نوع درون و بين آزمودنىها است كه ·r دختر شركت كننده در كلاسهاى تربيت بدنى عمومى دانشگاه خوارزمى در آن شركت كردند كه به صورت تصادفى از بين تمامى دختران حاضر در كلاسهاى تربيت بدنى عمومى دانشخاه انتخاب شده بودند. اين افراد به صورت داوطلبانه در اين يزوهش شركت كردند و از همه انها فرم رضايتنامه كرفته شد.

\section{ابزار اندازه كيرى}

در اين آزمايش از آزمون سرويس بكهند بدمينتون استفاده شد در اين آزمون زمين سمت راست بدمينتون به V نقطه تقسيم شد و به هر سرويس امتيازهاى از · تا V تعلق مى گرفت. براى هر تويى كه در منطقه خارج از زمين فرود مى آمد، امتياز صفر در نظر كرفته مى شد (شكل ()).

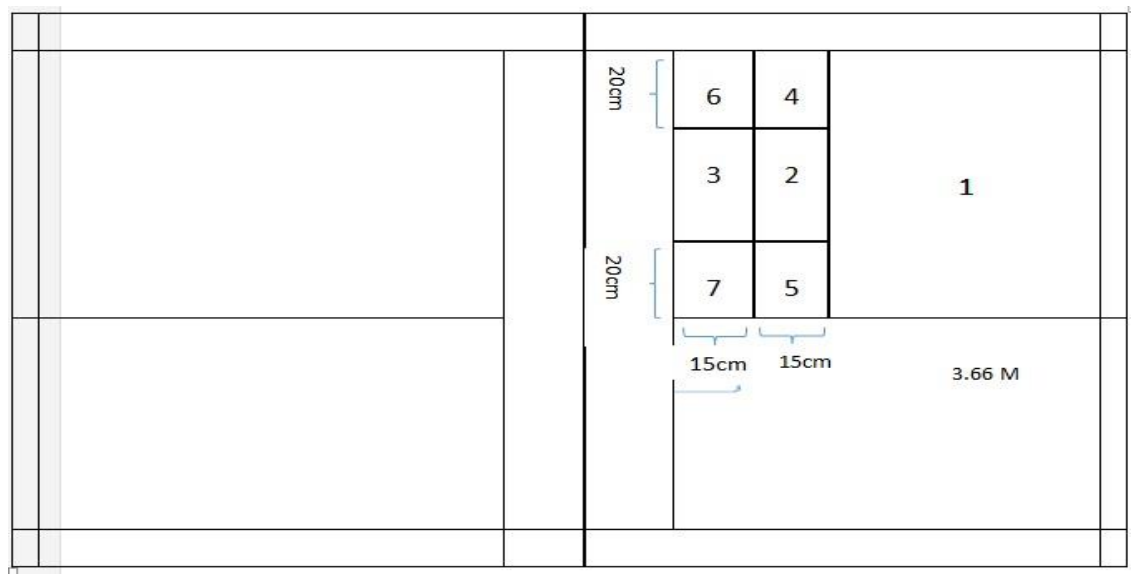

شكل ازمين بدميتون و نحوه امتياز دهى

https://jrsm.khu.ac.ir/ 


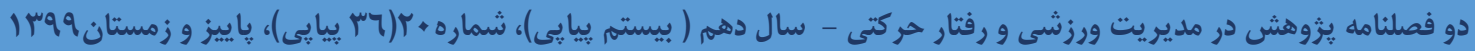

تكليف ثانويهاى كه در اين تحقيق انتخاب شد بِاخ به يك محرى صوتى بود كه از آن براى ثبت زمان واكنش كاوش استفاده شد. از يك لِّتاب استفاده شد كه يك بلندگو براى يخخش و يك ميكروفن بىسيم براى ضبط صدا به آن متصل

از نرمافزار تحت ويندوز آدسيتى'نسخه ع·r/ استفاده شد. از اين نرمافزار براى ثبت محرك صوتى و ياسخهاى شركتكنند كان استفاده شد. اين نرمافزار داراى اين قابليت است كه مىتوان توسط آن صداهاى بخششده در محيط را به صورت ديجيتال ضبط كرد. اين نرمافزار طيفى از شدت صوت بر حسب زمان توليد مىكند و توسط ويزكىهاى طيفسنجى آن مى توان فواصل زمانى دلخواه را شناسايى و اندازهگيرى كرد. مشابه روش استفادهشده در يزوهشهاى قبل (V-9)، زمان واكنش به صورت فاصله زمانى بين توليد محرى صوتى توسط رايانه تا زمانى كه شدت صوت ياسخ شركت كننده به dB / • برسد تعريف شد. به وسيله ابزار ويزه موجود در نرمافزار آدسيتى آستانه شدت صوت روى /dB • تنظيم شد. اولين نقطهاى كه امواج صوت ضبطشده به اين آستانه تعريفشده مىرسيد به عنوان زمان واكنش تعيين شد.

$$
\text { زمان واكنش با دقت S ا + • • اندازه كيرى شد. }
$$

محرى صوتى به صورت دستى و توسط يكى آزمون گر باتجربه ارائه مىشد. اين محرى صداى بيڤٍ از مجموعه صداهاى

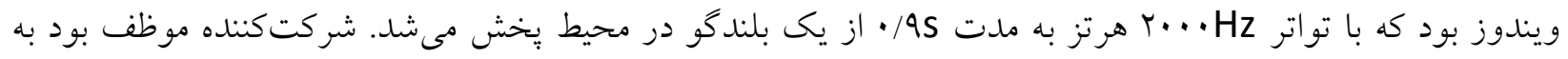
محض شنيدن اين صدا با دميدن در سوتى كه در دهانشان قرار داشت در سريعترين زمان ممكن به آن پاسخ دهد. ياسخ ورزشكار توسط ميكروفن بى سيمى كه روى سر ورزشكار نصب شده بود و در نزديكترين محل به دهان قرار داشت،

$$
\text { تشخيص داده مىشد. اين ميكروفن به صورت بىسيم به لٍ تاٍ متصل بود. }
$$

\section{روش اجـرا}

براى هر شركت كننده اندازهگيرىها در يك جلسه اختصاصى انجام شد كه حداكثر 0ح دقيقه طول مى كثيد. آزمونها در يك سالن سريوشيده و داراى زمين بدمينتون استاندارد و خالى از تماشاجى اجرا شد. شركت كنندكان با دست برتر، راكت شخصى، و توتهاى استاندارد سروها را اجرا كردند. بيش از شروع، كليه مراحل اجراى آزمون براى هر شركتكننده

\footnotetext{
${ }^{1}$ Audacity
}

https://jrsm.khu.ac.ir/ 


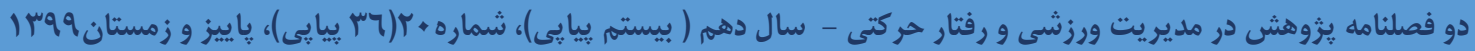

توضيح داده شد. سبس از ورزشكار خواسته شد به مدت ده دقيقه بدن خود را گرم كند و تعداد محدودى (حداكثر •(1) سرو را براى گرم كردن خود اجرا كند.

مراحل اندازه گيرى به اين شرح انجام شد. يُ از گرم كردن ابتدايى زمان واكنش يايه BL-RT هر شركت كننده اندازه گيرى شد. به اين صورت كه يس از كفتن كلمه "الماده" محرى صوتى براى ورزشكار ارائه مىشد و از او خواسته شد يس از شنيدن اين صدا با دميدن در سوت به آن ياسخ دهد. اين عمل با بار تكرار و ميانكين زمانهاى ثبتشده به عنوان عملكرد پايه تكليف ثانويه ثبت شد. محرك صوتى بِ از يك بيش دوره متغير دو تا جهار ثانيهاى ارائه مىشد. با تغيير زمان ارائه اين محرك به شكل نامنظم احتمال بيشبينى كم شد.

به شركت كنندكان كفته شد تكليف اصلى اجراى سرو است. روش امتيازدهى براى آنها توضيح داده شد و به آنها كفته شد كه بايد سعى كنند در مجموع بيشترين امتياز ممكن را كسب كنند. هر ورزشكار با دست ترجيحى خود VY سرو دسته rا كوششى) را اجرا كرد. ابتدا Y ا سرو بدون ارائه محرك صوتى (بدون ثبت زمان واكنش) اجرا شد. امتياز اين سروها ثبت و يس از محاسبه ميانخين به عنوان عملكرد يايه تكليف اصلى (عملكرد يايه بدمينتون BL-BP) در نظر كرفته شد. در ادامه شركت كننده •7 سرو ديخر اجرا كرد. در طول اجراى اين سروها به صورت نامنظم محرى شنيدارى در ب موقعيت كاوش ارائه شد. موقعيت كاوش اول (PP1) از لحظه كرفتن توبٍ تا قرار كرفتن در موقيعت زدن سرو و قبل از شروع حركت (تصميم كيرىهاى قبل از حركت يا مرحله آمادكى)؛ موقعيت كاوش دوم (PP2) از زمان شروع حركت راكت تا برخورد توبٍ با راكت و موقعيت كاوش سوم (PP3) پِس از ضربه تا انتهاى حركت بود. براى جلو گيرى از

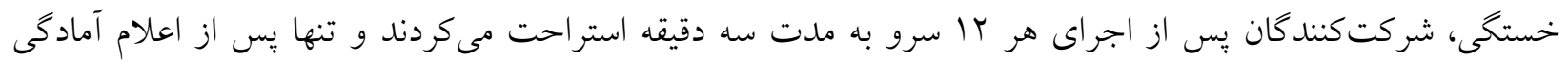
ورزشكار، آزمون ادامه مى يافت. براى كم كردن احتمال ييشبينى زمان ارائه محرك صوتى، به صورت نامنظم از كوششهاى مج گيرى استفاده شد. در اين كوششها تكليف ثانويه صوتى ارائه نمىشد و تنها امتياز سرو ثبت مىشد. كوششهاى مج كيرى از يك طرف اثر ييشبينى شركت كنندگان را كاهش مىدهد و باعث حفظ تمركز ورزشكار روى اجرا تكليف اصلى مى شود و از طرف ديخر باعث مىشود دقت زمانهاى واكنش ثبتشده در كوششهايى كه تكليف كاوش ارائه

\footnotetext{
2 Baseline tennis performance (BL-BP)

3 Pre-movement decisions or preparation period

${ }^{4}$ Catch trials
}

https://jrsm.khu.ac.ir/ 


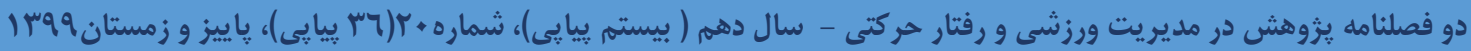

مىشود بالا برود. ارائه نامنظم محرى صوتى در موقعيتهاى كاوش و استفاده از كوششهاى مج گيرى مشكلات روششناختى را به حداقل مىرساند (• (1). اين يروتكل تحقيقى از يزوهش هاى مشابه اخذ كرديد (11). در مرحله بعد شركت كنندگان به صورت تصادفى به دو گروه تقسيم شدند و كليه مراحل بالا در مورد سرو مجددا اجرا كرديد با اين تفاوت كه به يك كروه دستورالعمل توجه داخلى داده شد (تمركز بر مج دست به شكلى كه حركت فقط با فلكشن و اكستنشن مج دست انجام كيرد و آزمودنى در كل اجراى حركت بر حركت صحيح مج دست تمركز مى كرد) و به گروه دوم دستورالعمل توجه خارجى ارائه ميخرديد ( از اين افراد خواسته شده بود توجه خود را به نقطه اي كه بيشترين امتياز را براى انها دارد معطوف كنند. براى اطمينان از اجراى صحيح دستورالعمل در يايان هر دسته تمرينى از انها در مورد دستور العمل اجرا شده به صورت شفاهى سوالاتى برسيده مى شد.

\section{تجزيه و تحلـيل آمارى}

متغير وابسته اصلى ميانخين زمانهاى واكنش موقعيتهاى كاوش سه گانه (RT-PP1، RT-PP3، RT-PP2) و پِيه -BL بود. ديخر متغير وابسته ميانخين مجموع امتيازهاى عملكرد يايه تنيس BL-BP و مجموع امتيازهاى سرو در شرايط

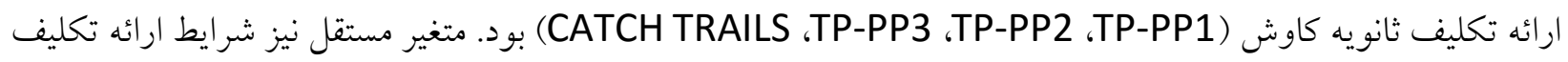
ثانويه كاوش بود.

براى اطمينان از اين كه تكليف اصلى براى شركت كنندگان اولويت داشته يا نه، عملكرد سرو در شرايط بِيه و كاوش با استفاده از آزمون تى استودنت (t-student) براى نمونههاى وابسته مقايسه شد. براى تعيين زمانبندى توزيع نيازهاى توجه، زمانهاى واكنش ثبتشده با استفاده از يك طرح تحليل واريانس با تكرار سنجش روى عامل شرايط آزمايشى ارائه تكليف ثانويه به عنوان متغير مستقل مورد بررسى قرار گرفت. براى مقايسه دو گروه در مورد زمان واكنش در نقاط كاوش متفاوت از آزمون تحليل واريانس مختلط استفاده شد. 


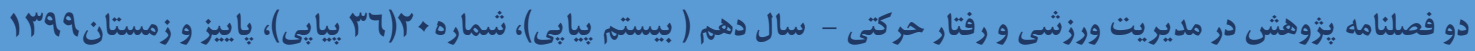

إفته ها

\section{عملكرد سرو}

نتايج آزمون تى استودنت نمونههاى وابسته براى تكليف اصلى نشان داد ميانخين (t|نحراف استاندارد) امتيازهاى اجراى

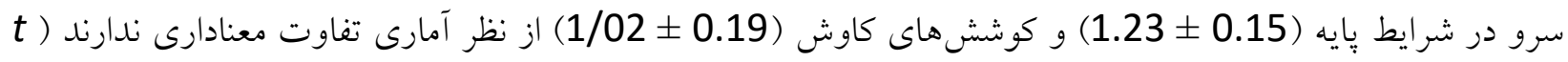

$$
((29)=0.91, p=0 / 37
$$

\section{زمان واكنش}

نتايج اجراى تحليل واريانس با تكرار سنجش نشان داد در كل شرايط آزمايشى روى زمانهاى واكنش ثبتشده اثر معنادار داشته است بايه داراى كمترين مقدار بوده و داراى اختلاف معنى دار با زمان واكنش در بقيه نقاط كاوش بوده است ( > RT-PP1) > 0.05 > 0.001, p(RT-PP2) > 0.001, p(RT-PP3). همجنين زمان واكنش در نقطه كاوش اول با دو نقطه كاوش ديخر اختلاف معنى دار داشته است (PP1-PP2) > 0.001, p(PP1-PP3) > 0.001 ) اما بين زمين واكنش در نقطه

$$
\text { كاوش دوم و سوم اختلاف معنى دارى وجود نداشته است (جدول ()). }
$$

مقايسه زمان واكنش پايه با زمان واكنش نقاط كاوش به صورت جداگانه در دو گروه با استفاده از آزمون تحليل واريانس با تكرار سنجش انجام گرفت. نتايج نشان داد كه هم در گروه دستور العمل توجه درونى (>

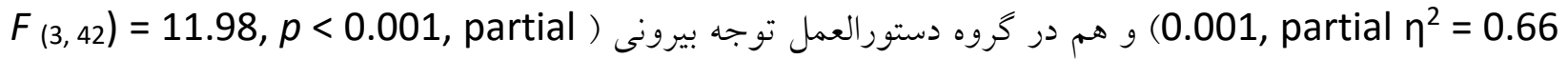
بين زمان واكنش پايه با زمان واكنش در نقاط كاوش تفاوت معنى دارى وجود دارد. آزمون تعقيبى بنفرونى 0.63 در كروه توجه درونى نشان داد كه بين زمان واكنش بايه و زمان واكنش در نقطه كاوش اول تفاوت معنى دارى وجود دارد همجنين بين زمان واكنش در نقطه كاوش اول و زمان واكنش در نقطه كاوش سوم نيز در اين كروه تفاوت معنى دارى يافت شد (PP1-PP3) > 0.05 (PP). بقيه زمانهاى واكنش در اين گروه تفاوت معنى دارى با يكديخر نداشتند.

در گروه دستورالعمل توجه خارجى نيز نتايج دقيقا به همين شكل بود. بين زمان واكنش يايه و زمان واكنش در نقطه كاوش اول و زمان واكنش در نقطه كاوش اول با زمان واكنش در نقطه كاوش سوم تفاوت معنى دار مشاهده شد (-RP1 


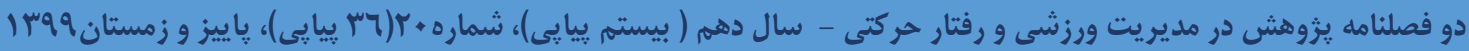

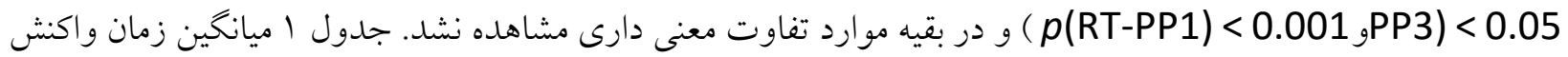
در سه مرحله ازمايش در گروه هاى مختلف را نشان مى دهد.

جدول ا ميانگين زمان واكنش گروههاى مختلف در مراحل مختلف آزمايش

\begin{tabular}{|c|c|c|c|}
\hline دستورالعمل توجه بيرونى & دستورالعمل توجه درونى & بدون دستور العمل & \\
\hline$\cdot / r \Lambda$ & $\cdot / \mu$ & $\cdot / 7 q$ & زمان واكنش پيايه \\
\hline$\cdot / \varepsilon r$ & $.10 \mathrm{~V}$ & . $10 \mathrm{r}$ & نقطه كاوش اولش در \\
\hline$\cdot / \mu$ & $\cdot / \varepsilon 7$ & $\cdot / \varepsilon r$ & نقطه كاوش دواكش در \\
\hline$\cdot / \mu$ & $\cdot / \varepsilon \varepsilon$ & $\cdot / \mu V$ & نقطه كاوش سوم \\
\hline
\end{tabular}

مقايسه نتايج زمان واكنش بين دو گروه در نقاط كاوش متفاوت با استفاده از آزمون تحليل واريانس مختلط نشان داد كه

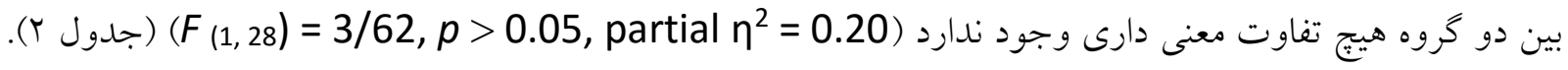
جدول ب نتايج آزمون تحليل واريانس مختلط

\begin{tabular}{|c|c|c|c|}
\hline Partial Eta Squared & F & F & \\
\hline .966 & .000 & 399.657 & ترونى \\
\hline .206 & .078 & 3.626 & تعامل \\
\hline
\end{tabular}

براى مشخص كردن اينكه دو كروه در كدام نقطه كاوش با يكديخر تفاوت معنى دار دارند به صورت تك تكى بين زمان واكنش دو گروه در هر نقطه كاوش ازمون تى استودنت انجام گرفت ولى از آنجايى كه هفت ازمون آمارى به انجام رسيد مقدار خطاى اول مورد يذيرش، 0 • • در نظر گرفته شد. نتايج آزمون تى استودنت نشان داد كه دو گروه در هيج كدام از نقاط كاوش تفاوت معنى دارى در زمان واكنش ندارند. 


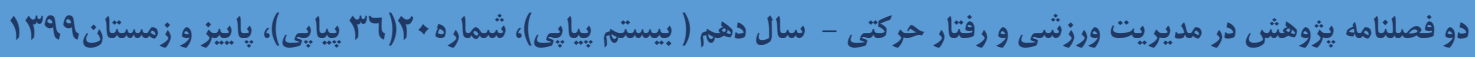

بحث و بروسى

اين يزوهش براى بررسى توزيع نيازهاى توجهى ههارت سرويس بكهند بدمينتون و همجنين بررسى بيش بينى هاى نظريه عمل محدود شده به انجام رسيد. با مقايسه دقت اجراى سرويس در زمانى كه تكليف كاوش ارائه شده بود (در مقابل بلدون تكليف كاوش) مشخص شد ميانخين نمرات دقت اجرا در هر دو مرحله مشابه بود بنابراين مى توان نتيجه كرفت تاكيد افراد ابتدا بر اجراى صحيح سرويس بوده است لذا مى توان با مقايسه زمان واكنش در موقعيت هاى كاوش مختلف به بررسى توزيع نيازهاى توجهى اين مهارت يرداخت. اولين نتيجه اى كه از بررسى زمانهاى واكنش به دست امد اين بود كه زمان واكنش به محرك صوتى در حين اجراى مهارت به صورت معنى دارى بيشتر از زمان واكنش بايه بود و اين نتيجه نشان مى دهد مهارت سرويس بكهند بدمينتون مهارتى است كه به صورت كاملا خودكار اجرا نشده و نيازمند توجه است. همجنين نتايج مرحله اول تحقيق نشان داد اولين بخش اجراى سرويس بكهند بدمينتون بيشترين نياز به توجه را دارد. از انجايى كه تحقيقات قبلى نشان داده اند مهارت هاى داراى بخش هاى قابل تفكيك در بخشهاى مجزا مى توانند به صورت كاملا متفاوت تحت تاثير محدوديت هاى توجهى قرار بخيرند اين يزوهش اين تفسير را تاييد كرد.

مقايسه زمانهاى واكنش به محرى كاوش RT-PPS با يكديكر نشان داد بيشترين و كمترين زمان واكنش به ترتيب متعلق به PP1 و PP3 است. بنابراين بر اساس منطق تكليف دو گانه، در اجراى سرويس بكهند بدمينتون بيشترين بار توجه در PP1 و كمترين در PP3 تقسيم شده است. در تحقيقات قبلى مشخصشده كه در اجراى سرو (1)) و دريافت واليبال (9)، يرتاب آزاد بسكتبال (•(1)، ضربه يُنالتى فوتبال (r (1)، و بازى كرلينگ (9)، مرحله آمادهسازى بيش از اجرا بيشتر از ديخر بخش هاى اجراى مهارت نياز به توجه دارد. در تحقيق حاضر نيز همين نتيجه به دست آمد. بيشتر ورزشكاران در رشته هاى مختلف ورزشى، بيش از اجراى اغلب مهارتهاى بسته و در مرحله آمادهازى مىكوشند تا با انجام اعمالى خاص و كليشهاى (روتين)به يك وضعيت مطلوب برسند. اين رفتارهاى قالبى علاوه بر افزايش تمركز و كاهش اضطراب، باعث فعال شدن حالات زيستشناختى و ذهنى مناسب مىشوند (rا و ع ()). علاوه بر اين به نظر مىرسد در اين مرحله ورزشكار برنامه حركتى صحيح براى اجر اى سرو را انتخاب مى كند. بنابراين مىتوان بيان داشت كه توجه به اجراى روتين

\footnotetext{
${ }^{5}$ Curling

${ }^{6}$ Routine
}

https://jrsm.khu.ac.ir/ 


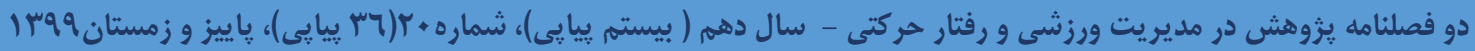

و انتخاب برنامه حركتى باعث بالا رفتن سطح نيازهاى توجه شده است. تحقيقات قبلى نيز نشان دادهاند كه سطح نيازهاى توجه مرحله آمادهسازى بيش از اجراى مهارتهايى ورزشى بسته بالاست ( •1-7). از طرفى در بخش دوم مهارت سرويس از انجايى كه نياز زيادى به هماهنكى توبٍ با راكت وجود ندارد (توبٍ ٍِتاب نميشود و تقريبا جِسبيده به صفحه راكت است) نياز توجهى زيادى را طلب نميكند همجنين در بخش سوم مهارت نيز ازمودنى هاى غير ماهر شايد كمتر اهميتى براى تعقيب توبٍ و نتيجه سرويس خود قائل هستند به همين دليل اين دو بخش نياز توجهى كمترى دارد البته از انجايى كه اجراى صحيح توالى حركات مج و دستى كه راكت را كرفته است همجنين هماهنگ نمودن زمان رها كردن توبٍ با زمان حركت راكت، نيازمند برنامه ريزى صحيح حركتى در سيستم بردازش اطلاعات است اين بخش به نسبت بخش سوم حركت، بيشتر توجه طلب است.

از طرفى نتايج تحقيق نشان داد تغيير در نوع تمركز توجه تاثيرى در ميزان توجه طلبى مهارت ايجاد نميكند كه اين مخالف نظريه عمل محدود شده و بيش بينى هاى ان است. نتايج نشان داد كه نه تنها تمركز توجه بيرونى تغييرى در ميزان توجه طلبى در مراحل مختلف مهارت ايجاد نكرد حتى مقدار كلى توجه مورد نياز نيز كاهش معنى دارى نداشت. اين نتيجه مخالف نتايج تحقيق ولف و همكاران (11) (7) مى باشد دليل اين تفاوت در نتيجه را مى توان به نوع مهارت (مجرد در مقابل مداوم در تحقيق انها) نسبت داد. بر خلاف مهارت هاى مجرد كه در زمان كوتاهى اجرا مى شوند، مهارت هاى مداوم به دليل ذات ييخردى خود و توجه طلبى زيادتر، شايد بيشتر تحت تاثير تمركز توجه بيرونى قرار ميخيرند. بر طبق نظريه عمل محدود شده يكى از دلايل بهبود اجرا و حتى يادكيرى با دستورالعمل تمركز توجه بيرونى، كاهش نيازهاى توجهى در مهارت است. اين كاهش موجب ميشود كه كنترل حركت به شكل خودكار انجام گردد و ميزان دركيرى سيستم عصبى مركزى به حداقل برسد. البته مقدار قابل توجهى از بهبود اجرا هم به كاركردهاى جسمانى مرتبط مى گردد كه مورد بحث اين تحقيق نيست. بايد به اين نكته توجه داشت نتايج امارى با توجه به ضريب خطاى بسيار كمتر از حد معمول اين نتيجه را به دست داده اند (به دليل تقسيم 0 • • بر V) به همين دليل شايد مقدارى سخت گيرانه، تفاوتى بين گروهها گزارش نشده باشد اما اخر اين نتايج را بيذيريم دلايل تفاوت بين توجه درونى و بيرونى را بايد در جايى ديخر جستجو 


$$
\begin{aligned}
& \text { به طور كلى اثرات مثبت دستور العمل تمركز توجه بيرونى غير قابل انكار است و به مربيان در جهت به كار گيرى ان توصيه } \\
& \text { مى كردد اما دلايل وقوع جنين اثراتى به نظر هنوز به صورت كامل شناسايى نشده و نياز به تحقيقات بيشتر دارد. مقايسه } \\
& \text { دو مهارت مجرد و مداوم و به كارگيرى جلسات تمرينى بيشتر به نظر راهكارى براى تحقق اين هدف است. }
\end{aligned}
$$

1.Ducharme SW, Wu WF, Lim K, Porter JM, Geraldo F. Standing long jump performance with an external focus of attention is improved as a result of a more effective projection angle. The Journal of Strength \& Conditioning Research. 2016 Jan 1;30(1):276-81.

2. Bell JJ, Hardy J. Effects of attentional focus on skilled performance in golf. Journal of Applied Sport Psychology. 2009 May 6;21(2):163-77.

3. Lohse K, Sherwood DE. Defining the focus of attention: effects of attention on perceived exertion and fatigue. Frontiers in psychology. 2011 Nov 14;2:332.

4. Porter JM, Ostrowski EJ, Nolan RP, Wu WF. Standing long-jump performance is enhanced when using an external focus of attention. The Journal of Strength \& Conditioning Research. 2010 Jul 1;24(7):1746-50.

5. Wulf G, McNevin N, Shea $\mathrm{CH}$. The automaticity of complex motor skill learning as a function of attentional focus. The Quarterly Journal of Experimental Psychology Section A. 2001 Nov;54(4):1143-54.

6. Wulf G, Lewthwaite R. Effortless motor learning? An external focus of attention enhances movement effectiveness and efficiency. Effortless attention: A new perspective in attention and action. 2010 Apr 9:75-101.

7. Rose DJ, Christina RW. Attention demands of precision pistol-shooting as a function of skill level. Research Quarterly for Exercise and Sport. 1990 Mar 1;61(1):111-3.

8. Yaali R., Bahram A., Farrokhi A., Movahedi AR. Determining of the attention demanding in the Badminton Smash Hit. Journal of sport management and motor behavior. 2013; 9;17. 47-58. (in Persian)

9. Castiello U, Umiltà C. Temporal dimensions of mental effort in different sports. International Journal of Sport Psychology. 1988. 
10. Price JL. Accuracy of free throw shooting during dual-task performance: Implications of attentional disruption on performance. The University of North Carolina at Greensboro; 2008.

11. Salehi H, Ghazanfari A, Movahedi AR, Nezakat Alhosseini M. Time course of attention during a volleyball jumping-serve using a dual-task paradigm.

12. Carr BM, Etnier JL, Fisher KM. Examining the time course of attention in a soccer kick using a dual task paradigm. Human movement science. 2013 Feb 1;32(1):240-8.

13. Czech DR, Ploszay AJ, Burke KL. An examination of the maintenance of preshot routines in basketball free throw shooting. Journal of Sport Behavior. 2004 Dec 1;27(4):323.

14. Mccann P, Lavallee D, Lavallee R. The effect of pre-shot routines on golf wedge shot performance. European Journal of Sport Science. 2001 Dec 1;1(5):1-0. 